\title{
Development of New Methodology to Assess Effectiveness of Low-rise Housing Construction
}

\author{
Filiushina Kristina, Gusakova Nataliia, \\ Dobrinina Olga \\ Department of Economics and Urban Management \\ Tomsk State University of Architecture and Building \\ Tomsk, Russia. \\ E-mail: kri1617@yandex.ru
}

\author{
Minaev Nikolai \\ Department of Natural Resources Economics \\ National Research Tomsk Polytechnic University \\ Department of Economics and Urban Management \\ Tomsk State University of Architecture and Building \\ Tomsk, Russia.
}

\begin{abstract}
The given paper presents the new method to assess the effectiveness of low-rise housing projects based on the public-private partnership principles. The basic indicators of low-rise housing project effectiveness were defined. The possible options for the mentioned projects implementation were considered. The algorithm was suggested to assess the effectiveness of low-rise housing project based on the publicprivate partnership principles.
\end{abstract}

Keywords - effectiveness; assessment; low-rise housing; public-private partnership; quality

\section{INTRODUCTION}

Currently, complex construction of low-rise residential houses is mainly realized within the definite investment projects. These investment projects require development of new methodology to assess low-rise housing construction effectiveness and its quality. The mentioned projects are being implemented using novel technologies of low-rise construction, namely those aimed at increasing the demand for low-rise housing, provision of housing availability for the population, increasing the comfort of living, integration of sustainable methods of construction, application of environmentally-friendly materials, the reduction of a construction period, construction cost saving and involvement of public authorities into implementation of low-rise housing projects.

Analysis of investment projects that are being realized in lowrise housing construction defined the key requirements that are being currently applied to the low-rise house as follows:

1. Availability and safety of low-rise house.

2. Environmental friendliness and aesthetic facade.

3. Energy-efficiency.

4. Comfort of living, i.e.: convenient design, parking, improved building surrounding grounds.

\section{Developed infrastructure.}

All the necessary requirements applied to low-rise housing construction can only be introduced by realizing the projects of public-private partnership. Construction effectiveness for the private investor equals to the obtained profit. However, the government is involved in such kind of projects due to the reason that they solve the problems of housing availability, resettlement and demolishing of rundown and substandard housing. Moreover, these projects attract private investments into rural territories development. In this regard assessment of these projects effectiveness is required.

\section{LITERATURE REVIEW}

The issue of low-rise housing construction development was studied by many researchers, for instance V.S. Kazeikin, S.A. Baronin, A.G. Chernykh, A.N. Androsov considered the basic problems of low-rise housing construction development in Russia [1]. S.A. Baronin and P.G. Grabovyi [2] studied peculiar features and priorities of low-rise construction development in Russia. The design and construction issues of separate residential houses and complexes can be found in [3]. The mentioned issue was also studied by $[4,5]$.

The issue of effective designing and construction of lowrise residential houses was considered by means of extensive analysis in [3]. The mentioned study focuses on development and application of the theoretical model of individual living environment as well as designing on the basis of integral, scientifically justified doctrine, the general concept and private principles of high-quality housing formation.

Professor $[6,7]$ conducted studies on development of lowrise construction, namely the author suggested classification of objects of low-rise construction, as well as conducted financial risks assessment for the participants of low-rise construction. E.K. Ivakin in his monograph introduces proprietary methodology suggesting the use of institutional theory and behavioral economics for investment provision on housing market $[8,9]$.

The issues of low-rise housing construction from the point of energy efficiency were considered by S.G. Sheina who studied theoretical, research and practice peculiarities as well as used the methods of integrated analysis of housing construction development. Special attention was paid to the problems and development prospects of low-rise construction with integrated energy-efficient solutions, the schemes of factor influence on low-rise construction development [5]. 
Russian scientists conducted studies of low-rise construction aimed at formation of new methodological principles of low-rise construction development, e.g. S.A. Prigarin conducted justification and developed methodology of innovative management of low-rise housing construction based on the integrated approach using the methods of strategic, program-oriented and project management [10]. A.M. Krygina suggested new institutionaleconomic and institutional-management decisions in low-rise construction [11]. According to I.E. Faizullin priority direction of low-rise construction in Russia was introduction of the integrated system approach [12].

Foreign literature provides a lot of data on implementation of investment construction projects in different branches of economy, based on the public-private partnership principles [13-17], and that experience can be easily implemented into Russian practice of low-rise housing. T.V. Ageeva focuses her research on assessment of low-rise construction effectiveness $[18,19]$. The basis of her research is centered on determination of expenses during economic effectiveness calculation of low-rise construction innovation-investment projects. I.V. Popova, N.N. Boroukhina, O.V. Petrosova conducted effectiveness calculation of low-rise housing construction development taking Penza Region as an object of study [20]. O.V. Buyanov and A.A. Gorbunova in their study [21] proved inefficiency of governmental support of entrepreneurship in the field of low-rise housing construction. The issues of assessment of low-rise housing projects effectiveness were also studied by O.M. Repina and E.O. Repina [22], L.V. Averina and A.A. Vasilieva [23]. However, these studies were devoted to assessment of low-rise construction in general or effectiveness assessment of publicprivate partnership projects. The issue of effectiveness assessment applicable to low-rise construction based on public-private partnership principles was not studied before.

Detailed analysis of published works [24-27] enables one to make a conclusion that the issue of low-rise construction development can currently be considered as a relevant one. There is still a number of issues requiring a detailed study, such as effectiveness assessment of low-rise housing project implementation at all the stages of construction, quality assessment of the final ready object and possible risks assessment occurring while this project realization, etc. Thus, the results of the given study are aimed at development of theoretical background on effectiveness assessment of lowrise housing construction based on the public-private partnership principles [28].

\section{METHODOLOGY}

In order to develop the new methodology to assess the effectiveness of low-rise housing construction based on the public-private partnership principles, it is necessary to highlight the key effectiveness indicators in low-rise construction (Fig.1).

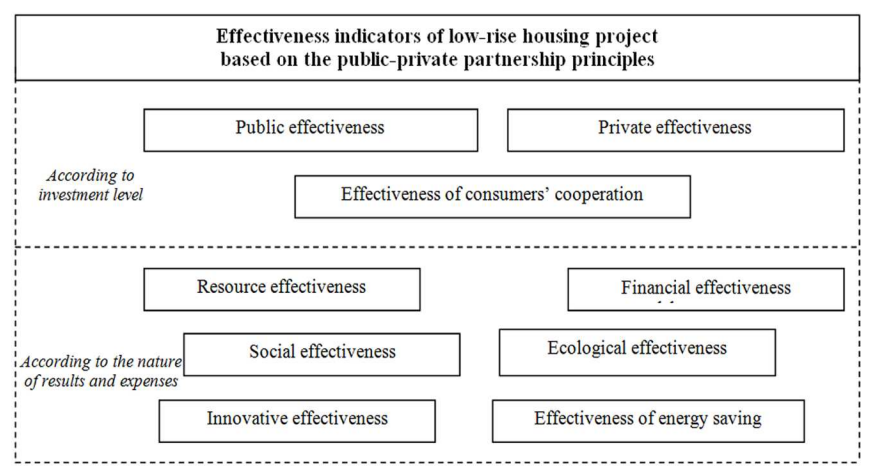

Fig. 1. Effectiveness indicators of low-rise housing project based on the public-private partnership principles.

1. According to the indicator "investment level", the effectiveness of low-rise housing projects can be classified into:

- public effectiveness (i.e. how effective the investments into low-rise housing are for the state, regional or local budget);

- private effectiveness (i.e. how effective the investments into low-rise housing are for private investors);

- effectiveness of consumers' cooperation (i.e. how effective the investments into low-rise housing are for consumer (population)).

2. According to the indicator "the nature of results and expenses", the effectiveness of low-rise housing projects can be classified into:

- financial effectiveness (effectiveness of income and expenditures of the project);

- resource effectiveness (the level and necessity of using required resources in low-rise construction);

- social effectiveness (social consequences occurring during implementation of low-rise housing project for all the project participants);

- ecological effectiveness (impact on environment during low-rise project implementation);

- innovative effectiveness (degree of innovative attractiveness of low-rise housing project);

- effectiveness of energy saving (introduction of energy saving measures into the project).

Effectiveness assessment of low-rise housing project is to be conducted at all the stages of construction, starting from design works up to land improvement. Fig. 2 shows the options for implementation of low-rise housing project based on public-private partnership principles.

Thus, it can be seen that there are several options for realization of such projects. The exact option is defined by the degree of participation of a public or private investor, and the income from final project is divided accordingly. 
The algorithm of effectiveness assessment of low-rise housing construction projects based on public-private partnership principles is given in Fig. 3.

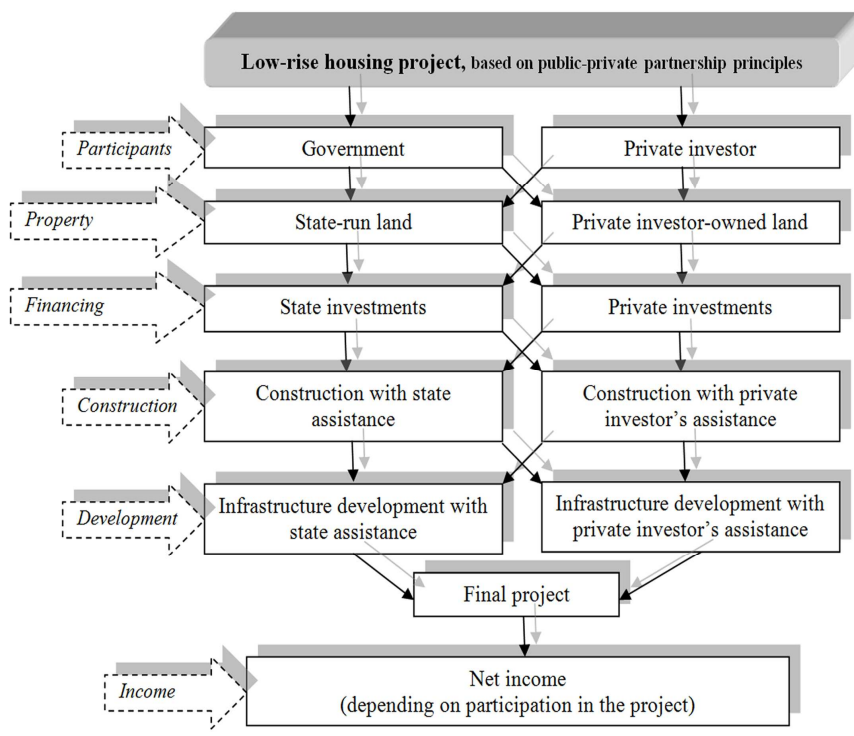

Fig. 2. Options for realization of low-rise housing project based on publicprivate partnership principles.

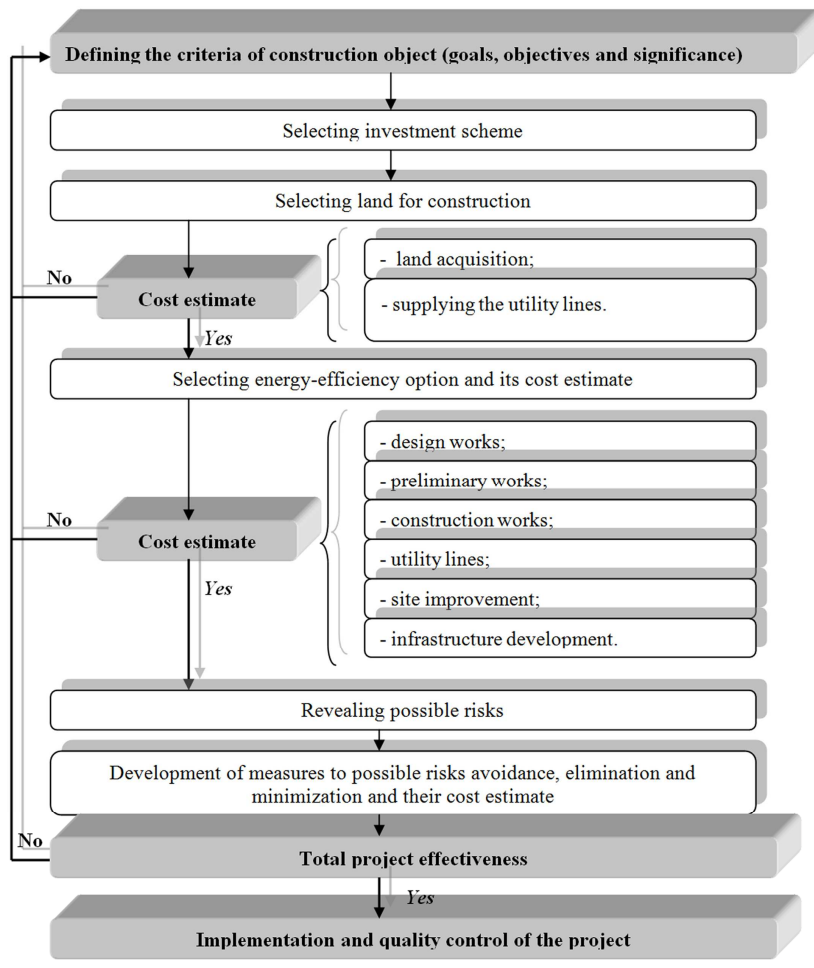

Fig. 3. Algorithm of effectiveness assessment of low-rise housing project.

The initial stage of planning of low-rise construction implies defining the initial data on the project, namely goals and objectives of construction, the significance of the given object of construction, site area, total area of the building, useful floor area, etc. Further step is defining the option for low-rise housing project realization (Fig. 2), i.e. the degree of participation of a public or private investor in the project. The site area for construction is selected and then the further issues are being solved, such as total area, current condition, cost and form of ownership. This stage should be provided with a cost estimate for land acquisition $\left(\mathrm{E}_{\mathrm{la}}\right)$ and supplying the necessary utility lines $\left(\mathrm{E}_{\mathrm{ul}}\right)$. Projects based on public-private partnership principles imply that land area for construction of low-rise housing is provided by government free of charge or on the basis of the long-term leasing agreement. Also the government finances and provides low-rise housing projects with the necessary utility services depending on the model of publicprivate partnership.

The national project "Available and provision of comfortable housing to the citizens of the Russian Federation" involves provision of land area for construction by the government free of charge. It also implies provision with all the necessary utilities thus enabling to reduce construction costs and cost of housing for the separate categories of people. The most effective option of low-rise housing development is suggested in the paper, i.e. construction of block-type low-rise houses. This type of low-rise construction will reduce significantly construction costs, therefore making it available for the benefit-entitled and social categories of people.

In case of obtaining the negative cost estimate for land acquisition and necessary utilities supplying, the project refers to the initial stage, and initial data on the project are being discussed. In case when the cost estimate is positive, the project proceeds to the next step, which is selection of energysaving option. Expenses for energy-efficient measures implementation $\left(\mathrm{E}_{\mathrm{e}-\mathrm{e}}\right)$ are also being estimated as follows:

$$
\mathrm{E}_{\mathrm{e}-\mathrm{e}}=\mathrm{E}_{\mathrm{des}}+\mathrm{E}_{\mathrm{tmf}}+\mathrm{E}_{\mathrm{us}}
$$

where $E_{\mathrm{des}}$ - expenses for energy-efficient measures while designing of building, rubles. These measures enable selecting the most optimal architectural and structural solutions able to increase energy efficiency of a low-rise building;

$E_{\mathrm{tmf}}-$ expenses for energy-efficient measures on integration of new technologies, materials and facilities, rubles. It enables to reduce materials and facilities consumption per product unit.

$E_{u s}$ - expenses for energy-efficient utility services, rubles. It further allows reduction of operation costs in low-rise housing.

Further step is the cost estimate of design works $\left(\mathrm{E}_{\mathrm{dw}}\right)$, preliminary works $\left(E_{p r}\right)$, construction $\left(E_{c}\right)$, utility lines $\left(E_{u s}\right)$, land improvement $\left(\mathrm{E}_{\mathrm{li}}\right)$, infrastructure development $\left(\mathrm{E}_{\mathrm{id}}\right)$. In case of significant expenses upon any kind of construction works the data is adjusted and corrected. In case of positive result the project proceeds to the next stage which is assessment and analysis of possible risks during project implementation. This stage is not always paid enough attention to, while possibility of risks occurrence can increase the expenses significantly. Risks identification is followed by development of measures to avoid, eliminating and mitigating them, as well as performing the cost estimate for these measures $\left(E_{a e m}\right)$. Authors suggest establishing a reserve fund 
on risks mitigation, comprising public and private investments, their share being defined individually depending on their participation in the project.

After calculation of expenses effectiveness, assessment of the project is being conducted according to the following formula $\left(\mathrm{E}_{\mathrm{pr}}\right)$ :

$$
\begin{aligned}
\mathrm{E}_{\mathrm{pr}}= & \left(\left(\mathrm{N} \cdot\left(\mathrm{N}_{\mathrm{f}} \cdot \mathrm{S}_{\mathrm{f}} \cdot \mathrm{C}_{1 \mathrm{sq} \cdot \mathrm{m}}\right)\right)+\left(\mathrm{C}_{1 \mathrm{dec}} \cdot \mathrm{S}_{\mathrm{l}}\right)\right)-\left(\mathrm{E}_{\mathrm{la}}+\mathrm{E}_{\mathrm{ul}}+\mathrm{E}_{\mathrm{e}-\mathrm{e}}(\mathfrak{Q})\right. \\
& \left.+\mathrm{E}_{\mathrm{dw}}+\mathrm{E}_{\mathrm{pr}}+\mathrm{E}_{\mathrm{c}}+\mathrm{E}_{\mathrm{us}}+\mathrm{E}_{\mathrm{li}}+\mathrm{E}_{\mathrm{id}}+\mathrm{E}_{\mathrm{aem}}\right) \rightarrow \max
\end{aligned}
$$

$\mathrm{N}$ - number of low-rise houses of block-type;

$\mathrm{N}_{\mathrm{f}}$ - number of flats in one block-type house;

$\mathrm{S}_{\mathrm{f}}-$ flat area, $\mathrm{m}^{2}$;

$\mathrm{C}_{1 \mathrm{sq} . \mathrm{m}}-$ cost per square meter, thousand rubles;

$\mathrm{C}_{1 \mathrm{dec}}-$ cost per 100 sq.m. of land, thousand rubles;

$\mathrm{S}_{1}-$ land area, 100 sq.m.

In case the effectiveness of low-rise housing project is low, than the project is referred to the initial stage, the initial project data is being discussed and the required corrections are being made. In case of sufficient effectiveness of low-rise housing project its implementation stage begins, followed by quality control of all the built houses at the project completion.

Quality control of low-rise housing project undergoes not only at the project completion, but also at every stage of construction, including quality control of building materials, structures and equipment; construction and installation works; separate kinds of works, as well as engineering supervision, designer supervision and architectural and building supervision.

While commissioning of the low-rise house, the quality control is performed subject to the Russian National Construction Codes SNIP 3.01.04-87 and Russian Standard GOST P 54964-2012.

The criteria for effectiveness assessment of low-rise house can be extended and defined by traditional way: ecological performance, safety and durability (reliability), energy efficiency, comfort, architectural attractiveness.

Considering the criteria mentioned above, the following quality assessments of low-rise housing are being conducted:

- the normative assessment, i.e. assessment of the house compliance with the standard indicators (of federal, regional, territorial, industry-based and local regulatory sources).

- the actual assessment, i.e. conducting actual measurements and comparison with the standard indicators;

- service evaluation, i.e. evaluation of the low-rise house from the consumer's point of view, and comparison with the standard indicators as well.

All listed criteria are general and each of them is divided into particular criteria for quality assessment of low-rise houses. For instance, the criterion of ecological performance of low-rise house includes assessment of influence on the environment and the use of natural building materials; the safety criterion includes assessment of fire safety; the energy- efficiency criterion includes heat and electric energy losses, assessment of energy efficiency class, etc. (Table 1).

TABLE I. The basic indicators of quality assessment of low-rise house and

\begin{tabular}{|c|c|c|}
\hline $\begin{array}{c}\text { Type of } \\
\text { assessment }\end{array}$ & The basic indicators & Assessment methods \\
\hline $\begin{array}{l}\text { Environmental } \\
\text { assessment }\end{array}$ & $\begin{array}{l}\text { - impact on air } \\
\text { environment; } \\
\text { - surface, ground and } \\
\text { deep-well water; } \\
\text { - soil; } \\
\text { - noise environment; } \\
\text { - flora and fauna; } \\
\text { - landscape and aesthetic } \\
\text { environment; } \\
\text { - sanitary-and- } \\
\text { epidemiological } \\
\text { environment; } \\
\text { - cultural-historical } \\
\text { heritage. }\end{array}$ & $\begin{array}{l}\text { Assessment method of the } \\
\text { impact significance; } \\
\text { comparative analysis; } \\
\text { normalization and } \\
\text { weighting method; } \\
\text { hierarchy analysis method. }\end{array}$ \\
\hline \multirow{2}{*}{$\begin{array}{c}\text { Safety } \\
\text { assessment }\end{array}$} & $\begin{array}{l}\text { - assessment of accidents } \\
\text { probability }\end{array}$ & $\begin{array}{l}\text { Analysis of space-planning } \\
\text { and structural solutions; } \\
\text { expert evaluation method; } \\
\text { calculation data or data } \\
\text { from on-site inspections; } \\
\text { method of logical fault tree. }\end{array}$ \\
\hline & - assessment of fire safety & $\begin{array}{l}\text { Visual inspection, } \\
\text { development of regulatory } \\
\text { documents and preparation } \\
\text { of employers for discharge } \\
\text { of their duties. }\end{array}$ \\
\hline $\begin{array}{l}\text { Durability } \\
\text { (reliability) } \\
\text { assessment }\end{array}$ & $\begin{array}{l}\text { - assessment of materials } \\
\text { and structures; } \\
\text { - assessment of } \\
\text { construction and } \\
\text { installation works; } \\
\text { - assessment of } \\
\text { construction methods; } \\
\text { - assessment of technical } \\
\text { condition. }\end{array}$ & $\begin{array}{l}\text { Visualization method; } \\
\text { methodological } \\
\text { recommendations and } \\
\text { tabular data for assessment } \\
\text { of observation results. } \\
\text { Instrumental measurements } \\
\text { by different equipment } \\
\text { based on physical, } \\
\text { radiological, electro- } \\
\text { magnetic and other impacts. }\end{array}$ \\
\hline $\begin{array}{l}\text { Energy } \\
\text { efficiency } \\
\text { assessment }\end{array}$ & $\begin{array}{l}\text { - assessment of heat } \\
\text { energy consumption for } \\
\text { heating and ventilation } \\
\text { - assessment of heat } \\
\text { energy consumption for } \\
\text { hot water supply } \\
\text { - assessment of electric } \\
\text { energy consumption } \\
\text { - assessment of using } \\
\text { secondary energy sources } \\
\text { - assessment of the use of } \\
\text { renewable energy sources }\end{array}$ & $\begin{array}{l}\text { Calculation data and } \\
\text { analysis of design } \\
\text { documents }\end{array}$ \\
\hline $\begin{array}{c}\text { Comfort } \\
\text { assessment }\end{array}$ & $\begin{array}{l}\text { - assessment of } \\
\text { infrastructure } \\
\text { attractiveness, } \\
\text { - assessment of acoustic, } \\
\text { light, air-thermal comfort }\end{array}$ & $\begin{array}{l}\text { Analysis of design } \\
\text { documentation, } \\
\text { visualization methods }\end{array}$ \\
\hline $\begin{array}{l}\text { Assessment of } \\
\text { architectural } \\
\text { attractiveness }\end{array}$ & $\begin{array}{l}\text { - aesthetic qualities level, } \\
\text { - quality of structural } \\
\text { solutions }\end{array}$ & $\begin{array}{l}\text { BIM - information } \\
\text { modeling of building, } \\
\text { analysis of design } \\
\text { documentation, } \\
\text { visualization methods. }\end{array}$ \\
\hline
\end{tabular}
their assessment methods.

The environmental assessment is conducted for the analysis or prediction of potential impacts on the environment and then their significance assessment is held. The actual values are assessed and then compared with the standard 
values and rules of environmental management. During the assessment of impacts on air environment the maximum permissible concentration of pollution agents is defined. During assessment of cultural-historical heritage it is considered if there are any limitations for the definite types of activities within specially protected areas or close by natural and cultural monuments.

Ranking assessment is performed as the next stage regarding the energy efficiency grade as specified in Standards of National Builders' Union STO NOSTROI 2.35.4-2011 "Ranking system of sustainability assessment of the living environment". Finally, the energy efficiency grade of low-rise house is defined and the decision on its commissioning is accepted.

\section{CONCLUSIONS}

Regarding the provided data, it can be concluded that effectiveness of low-rise housing construction depends on many indicators and its effectiveness assessment should be held at all the stages of project implementation. The basic indicator for population is availability of low-rise housing that can be reached by attraction of public authorities into projects realization and construction of block-type low-rise houses. Realization of such kind of projects provides cost reduction of low-rise houses due to saving money from land acquisition and necessary utility lines supplying, along with that infrastructure development in such project goes without saying. Therefore, effectiveness of low-rise housing projects based on public-private partnership principles is practically approved and requires further study.

\section{Acknowledgement}

The paper was prepared within the frameworks of the President of Russian Federation Grant No. MK-5341.2016.6 "Formation of concept-based regional governance model to stimulate the processes of public-private partnership projects implementation in low-rise construction considering the energy efficiency requirements".

\section{References}

[1] V.S. Kazeikin, S.A. Baronin, A.G. Chernykh, A.V. Androsov, Problemnye aspekty razvitiya maloetazhnogo zhilischnogo stroitelstva $\mathrm{V}$ Rossii [Challenges in development of low-rise housing construction in Russia]: Monograph. Edited by academician V.S. Kazeikin, 2011.

[2] S.A. Baronin, P.G. Grabovyi, Proceedings of the South-West State University", vol. 5-2 (38), pp. 48-58, 2011.

[3] A.N. Asaul, Y.N. Kazakov, N.I. Pasyada, I.V. Denisova, Teoriya i praktika maloetazhnogo zhilischnogo stroitelstva $\mathrm{v}$ Rossii [Theory and practice of low-rise housing construction in Russia], Edited by Prof. A.N. Asaul, 2005

[4] E.Y. Bondarenko, L.V. Ivanenko, Osnovy ekonomiki, upravleniya i prava [Fundamentals of economics, management and law], vol. 2(8), 2013.

[5] S.G. Sheina, E.N. Minenko, Razrabotka optimizatsionnoi modeli vybora energoeffektivnykh reshenii $\mathrm{v}$ maloetazhnm stroitelstve [Development of optimization model for selecting of energy-efficient solutions in lowrise construction]: monograph, 2013.

[6] E.K. Ivakin, A.V. Vagin, Inzhenernii Vestnik Dona [Engineering Journal of Don], Vol. 3 (21), pp. 555-560, 2012.
[7] E.K. Ivakin, A.V. Vagin, Vestnik MGSU [Proceedings of Moscow State University of Civil Engineering], Vol. 2, pp. 189-196, 2013.

[8] E.K. Ivakin, A.V. Vagin, Nauchnoe obozrenie [Scientific review],Vol.2, pp. 277-283, 2013.

[9] E.K. Ivakin, D.G. Ivanova, E.O. Mirgorodskaya, M.E. Semenov, Investitsionnoe obespechenie rynka zhiliya; institutsionalnii i povedencheskii podhody [Investment provision of the housing market: institutional and behavioral approaches], Rostov-on-Don, 2013.

[10] S.A. Prigarin, Ekonomicheskie nauki [Economic sciences], Vol. 5 (78), pp. 196-200.

[11] A.M. Krygina, Fundamentalnie issledovaniya [Fundamental research], Vol. 8-2, pp. 390-394, 2014.

[12] I.E. Faizullin, Regionalnaya ekonomika: Teoriya i praktika [Regional Economics: Theory and Practice], Vol. 30, pp. 44-48, 2010.

[13] L. O'Toole, J Publ Adm Res Theor, vol. 7, 1997.

[14] R. Rhodes, D. Marsh, Policy Network in British Politics. A Critique of Existing Approaches. Policy Network in British Government, 1992.

[15] World Bank Group Private Sector Development Strategy Implementation Progress Report, Washington, D.C., 2003.

[16] European Commission, Guidelines for Successful Public-Private Partnerships, 2003.

[17] 2007 Global Project Finance Yearbook Published by Standard \& Poor's, a Division of The McGraw-Hill Companies, Inc. Copyright (c) 2006 by The McGraw-Hill Companies, Inc.

[18] T.V. Ageeva, Financy. Ekonomika. Strategiya [Finances. Economics, Strategy], vol. 8, pp. 61-66, 2010.

[19] T.V. Ageeva, Rossiiskoe predprinimatelstvo [Russian entrepreneurship], vol. 5-1, pp. 114-122, 2011.

[20] I.V. Popova, N.N Boroukhina, O.V. Petrosova, Sovremennye problem nauki i obrazovaniya [Modern problems of science and education], vol. $6,2014$.

[21] O.V. Buyanov, A.A. Gorbunov, Vestnik natsionalnoi akademii turizma [Vestnik of national tourism academy], vol. 4 (36), pp. 100-103, 2015.

[22] O.M. Repina, E.O. Repina, Innovatsionnye technologii upravleniya i prava [Innovative technologies of management and law], vol. 2 (12), pp. 23-28, 2015.

[23] L.V. Averina, A.A. Vasilieva, Vestnik sobremennoi nauki [Vestnik of modern science], vol. 4-1 (16), pp. 71-76, 2016.

[24] Markku Karjalainen, Riku Patokoski Urbanized wooden villages. Helsinki. Rakennustieto, 168, 2009.

[25] Markku Lappalainen Energy, ecology and wooden construction. Accessed: http ://npadd.ru/index.php?a=pub\&id=846, 2009.

[26] Y. Mulen, Mechanisms of financial support while construction of social housing in Netherlands. Real estate, 2002.

[27] Ted Kesik, Michael Lio Construction of wooden frame houses by frame techology. Canadian mortgage and housing corporation, 311, 2004.

[28] K.E. Filiushina, N.N. Minaev, N.V. Gusakova, O.I. Dobrynina, E.A. Zharova, Y.A. Merkulieva, A.S. Runkova, Vestnik Tomskogo Gosudarstvennogo Arkhitekturno-stroitelnogo universiteta [Vestnik Tomsk State University of Architecture and Building], vol. 3 (56), pp. 166-178, 2016. 